\title{
Teacher Communication Effectiveness in the Learning Process
}

\author{
Ribut Priadi \\ Universitas Muhammadiyah Sumatera Utara, Indonesia \\ ributpriadi@gmail.com
}

\begin{abstract}
There are many aspects and aspects that can become the standard for the success or failure of an educational process. This aspect is usually present in the teacher as mentor, teacher and also on the side of students. One aspect that can be a barrier to the success of students in absorbing subjects from the teacher is the factor of communication that is not working effectively. Communication is very important considering that the educational process is currently directed into a room filled by teachers and students. In such conditions a two-way communication pattern is required, in order to create optimal interaction in each face-to-face between teachers and students, so that educational goals can be achieved. This paper will discuss the significance of teacher communication and its effect on student interest in learning.
\end{abstract}

Keywords

communication; learning, student interest

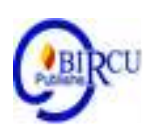

\section{Introduction}

The Quran says that the purpose of education is to foster humans individually and in groups so that they are able to carry out their functions as servants of Allah and His Caliph, in order to build the world in accordance with the concept established by Allah to be obedient to Him. (Qutb, 1400H: 13).

The educational process that humans experience and go through is quite long, namely as long as life is in the body's body, humans will continue to interact with people and other creatures around them (M. Akrim \& Harfiani, 2019; Nasrudin, Agustina, Akrim, Ahmar, \& Rahim, 2018). Likewise in formal educational institutions, the interaction process does not only occur unilaterally, but will involve various parties, namely between schools, families and communities (Akrim, Nurzannah, \& Ginting, 2018). But what is more specific is to improve student achievement. Therefore, the teaching and learning interaction process is a form of communication that is absolutely necessary ( $\mathrm{Mr}$ Akrim, 2018).

In the implementation of education and teaching, where good achievement is the hope of everyone, both students, teachers and parents expect good results for student learning progress (Agussani \& Akrim, 2020; Nurzannah; Akrim; Yunus, 2017). However, an achievement will not be obtained by students if there is no good communication, because the message conveyed by the teacher both through spoken, written and sign language must be understood and studied properly by students (Dadang; \& Akrim, 2020; Hartanto, Hidayat, \& Sazali, 2019; Hartanto, Radiman, \& Adhani, 2020).

Education can also be defined as the process of providing assistance by educators (teachers) to students to achieve a goal by selectively and effectively using tools (educational media) and taking place in a harmonious environment. As for what is meant, the assistance provided by educators to students is the actualization of the immanent potentials (fitrawi) that exist in students (Sulasmi, 2020). 
Communication in the teaching and learning process does not only involve communication on the part of students, but must be two-way communication. Students as the target of the communication carried out, must be able to understand and understand all the material presented, both intonation, body gestures and so on (Gunawan \& Sulasmi, 2020; Sulasmi, 2020b, 2020a). For students this is a form of totality that must understand all its aspects. This also shows that students must use all their senses in the learning process. If a communication between the teacher and the overall personal readiness of students does not have the same direction and purpose, what happens is a gap in the implementation of the communication itself (Prasetia, Akrim, \& Sulasmi, 2019; Sulasmi, 2019).

\section{Review of Literature}

\subsection{Definition of Communication}

Many experts provide a definition of communication, but in general they almost agree that communication is the process of delivering messages to other people who have the same understanding in responding to a message conveyed. T.A. Latief Rousydiy said that communication is the process of passing symbols which is the essence of the meaning of communication (Rousydiy, 1989: 49).

Hasbullah et al (2018) stated that communication is the process of sending messages from one party to another through certain contexts such as intrapersonal communication, interpersonal or interpersonal communication, group communication or organizational communication and mass communication. When communication takes place in the context of group communication or organizational communication, it will have its own communication network or pattern. Meanwhile according to Aminullah (2019) ommunication is a symbolic behavior that cannot be separated in human life. Communication also has existed since humans existed, so in this case communication becomes a necessity in his life. In addition, communication is also referred to as social interaction, because humans are social beings.

According to Astrid S. Susanto, communication is every teaching that wants to reach the general public and is intended to reach the wider community, who, with mental strength, try to convince other parties. Samsuddin and Ananda (2019) stated that communication is a process where individuals in their relationships with other individuals, in groups, in organizations, and in society to provide information. According to Soegarda Poerbawakatja communication is a term in education which means that between the educator (teacher, parent) and their student (student, child) a relationship is achieved that allows the educator to distribute educational materials (values) to the child (Poerbawakatja) and AH Harahap. 1976: 158).

Communication in learning to be more effective and efficient and to find targets to be used as a learning process in order to change the attitudes, opinions or behavior of students, then communication must be communicative, easy to understand, generate student stimulation. This means that communication must use the media which ultimately has a certain effect on students. In essence, in implementing communication, five elements of communication must be considered, namely:

1. Communicator (communicator, source, recipient).

2. Message (message).

3. Media (channel, media).

4. Communicate (communicate, communicatte, receiver, recipient).

5. Effect (effect, influence) (Effendy. 1993: 10). 
In communicating, in addition to the elements above, there is also a set of tools used as symbols or symbols that can be understood by the recipient of the message. The symbols used by fellow humans in communicating include:

1. Language, both spoken and written.

2. Cues.

3. The pictures.

4. Signs (Sastropoetro. 1990: 8)

Communication will also be successful when the message giver (teacher) and the message receiver (student) can pay more attention to the situation and conditions before the communication or teaching begins. In this connection R.A. Santoso Sastropoetro said that:

"Messengers also really need to pay attention to the atmosphere before conveying their messages or their information, because situations that are not compatible will certainly produce good results (as expected) in implementing the information."

When associated with learning, the teaching and learning process is an example of a type of communication. In this connection Abdullah Hanafi said:

"This type of teaching relationship clearly requires a contract between teacher and student. The teacher provides a systematic description of useful knowledge to students and provides opportunities and guidance to practice what is learned." (Hanafi. 1984: 55)

In the process of teaching and learning interactions, a teacher seeks to provide stimulation related to the teaching field. This stimulation is expected to get a response from students. How communication can encourage learning activities, then one of the symbols that effectively convey stimulation is language. This is as stated by M. Arifin:

Social communication by using language is one of the most effective forms of communication in the sense of the process of transmitting feelings, attitudes, realities, beliefs and ideals among humans (Arifin 1993: 78).

The most important communication in education as the definition above is how the description in the minds and contents of the consciousness of the teachers as communicators can be understood, accepted and even carried out by the communicant, namely students (A. Akrim \& Sulasmi, 2020).

In Islamic teachings, communication is very urgent, even people who get the safety of life, both in the world and in the hereafter are people who can build good communication with Allah SWT, then the second is good relations between fellow humans. If the communication between humans is good and the communication relationship with God Almighty will be good, then that person will be given the glory of God wherever they are. This is expressly stated in the Quran in Surah Ali Imran verse 112 which means:

"They are covered with humiliation wherever they are, unless they hold on to the rope (religion) of Allah and the rope (covenant) with humans, and they return to the wrath of Allah and they are covered with humility...

So it is clear that communication has existed since humans have lived in a society and is used to exchange ideas, establish relationships between humans, convey desires, experiences and so on.

\subsection{Definition of Learning}

Learning is a process of change. Change here means a change in the ability to think and behave as a result of experience, training and others (Agussani \& Bahri, 2019; Dadang; \& Akrim, 2020). This is reinforced by the opinion of Engkoswara and Sudirman 
regarding the definition of learning, namely: Learning is a process of changing behavior, which can be expressed in the form of mastery and assessment of knowledge, attitudes and values and skills (Engkoswara, et.all. 1999: 99).

When learning is associated with the process of change that occurs in humans, it is because of the thought process and human ability to react and communicate with the stimulation around them, so that changes in humans occur very quickly. In contrast to the process of change that occurs in other creatures such as animals. This is in line with $\mathrm{M}$. Arifin stated that:

"The ability of the inferior creature to the ability of humans, namely that in the lower beings, changes in behavior occur due to repeated experiences, while the changes are very slow. This is different from humans, changes in behavior occur because of the ability to think and the ability to react to stimulation (stimulation) that is nonphysical (not appearing around it), then the behavior change takes place very quickly." (Arifin. 1977: 181).

Humans were created by Allah Almighty as the most noble creatures when compared to other creatures created by Allah. The glory of man lies in his mind. With human intellect can take every lesson in his life. This was said by Allah SWT in Surah Albaqarah verse 269 which means:

... and no one can learn a lesson except those who are sensible.

Learning is a process of change. Change here means a change in the ability to think and behave as a result of experience, training and others (Amhar, 2020; Arifin, Agussani, \& Rudianto, 2019; Syar'i, Akrim, \& Hamdanah, 2020). Learning is a thought process. Thinking is the process of using reason optimally (Qorib \& Hartanto, 2020). This difference is explained by Allah in the Qur'an surah al-Zumar verse 9, which means:

Say: Are there people who know with people who don't? Truly wise people who can receive lessons. follows:

Educational experts argue that there are several principles of learning, namely as

1. Whatever the student learns, he must learn it himself; no one has to do these learning activities for him.

2. Each student learns at his or her own pace, and for each age group there are variations in learning speed.

3. A student learns more when every step is immediately reinforced.

4. Full mastery of each step makes learning more meaningful as a whole.

5. When students are given the responsibility to study on their own, they are more motivated to learn; he will learn and remember better. (Ivor K. Davies. 1991: 32)

Broadly speaking, the results of learning do not have to be measured when a teaching and learning event ends, but the results of the learning process, so that they can be assessed from various aspects, which include attitudes and behavior, knowledge, skills and so on. Engkoswara said that the results of the learning process can be seen in the form of:

1. Attitudes and values.

2. Is the result where students become:

a. Modeling (can imitate).

b. Contagion (infected), and

c. Osmosis (embraced), regarding the knowledge, skills, and attitudes of learning conditions, both those programmed by the teacher (this is what should be done) and those not programmed by the teacher.

In formal education, learning has been programmed in such a way as to achieve the goals of education itself, so that Harsja W. Bachtiar said that learning is: 
"It's a complex process that happens to everyone and lasts a lifetime, from when he was a baby to his grave. One of the signs that someone has learned something is a change in behavior in him. Changes in behavior involve both changes in knowledge (cognitive) and skills (psychomotor) and those concerning values and attitudes (affective)."

Thus, a person has been said to learn when there is a change in behavior in him. These changes should occur as a result of interactions with the environment, not due to fatigue, disease or the influence of drugs, except that the changes must be relatively permanent, long lasting and permanent, not lasting for a moment.

\section{Discussion}

\subsection{Communication Functions in Learning}

Basically, communication between teachers and students, there is a function to find obstacles or obstacles that can be directly encountered and dictated. Another advantage is that the backflow is meant how the reaction is given by the communicant. This reaction can be either positive or negative and can be sent to the communicator (teacher) directly or indirectly as feedback in order to overcome student learning difficulties. Communication between teachers and students can be grouped into types of social communication. In conducting this communication, there are three functions that can be found, namely:

1. Environmental care.

2. Connect separate sections of society to respond to the environment and

3. Passing down social inheritance from one generation to the next.

There are four communication functions between the teacher and students, namely:

1. Deliver information (to inform).

2. Educate (to educate).

3. Entertaining (to entertain).

4. To influence (Purwanto. 1994: 8)

The communication function between teachers and students contains self-interest and the interests of other parties (Agussani, 2020). Self-interest is the student's own interest for the success of the teaching and learning process carried out (Agussani, n.d.). The interests of others are the interests of teachers as well as parents and society in the successful achievement of educational goals (M. Akrim \& Harfiani, 2019). After the interaction occurs, the result is to prioritize yourself, the interests of other parties that are linked to self-interests and prioritize other interests (Sulasmi \& Akrim, 2020).

In looking at communication problems in learning, which is highlighted in the communication relationship between teachers and students, it can be clearly said that communication between teachers and students also includes the teacher's task patterns in arousing student interest and motivation (Priadi \& Rudianto, 2020).

Ibrahim Bafadel said:

.... "a teacher creates a teaching system in accordance with what has been previously planned. This task includes, among other things, opening and conveying teaching objectives, delivering subject matter, using certain methods and tools according to the plan, assessing student learning success, motivating, helping students solve problems." (Bafadel. 1992: 31)

As a communicator, the teacher's job is not only to convey messages of education and science to students, but more than that, teachers and students must both understand and understand the symbols and other tools and tools used in the world of education. explain its 
use and arrange the situations and conditions that support the communication process. so the teacher's duties include intra and extra. This was expressed by Zahara Idris:

"Teachers must organize intra and extra-class activities, student personal (organizer,

placement, assignment, tutor of students and class promotion), as well as class

facilities (seating arrangements, class room maintenance, arrangement of tools.

lessons, cleanliness, ventilation lighting and room acoustics."(Idris. 1981: 77)

In communicating between teachers and students, it is the teacher factor that is more dominant when compared to students. This is because teachers are people who provide information, people who know a lot and have an attitude of authority and physical and mental maturity. Therefore the teacher's function is not only as a message provider, but also able to arouse student motivation towards the subject matter to be presented. This was said by Engkosawara and Sudirman, namely:

"There is one thing that needs to be considered during student learning activities, namely the problem of student interest and attention to the subject matter presented. Here the teacher is required not only to act as a transformer, but also to function as a motivator, which can motivate students' interest in learning by using various media and sources that are appropriate and support the achievement of a goal."

Based on the description above, it is clear that the function of communication in learning is as a medium to emphasize / clarify, motivate, stimulate and motivate students to actively learn with messages and activities carried out by the teacher, none other than making optimal use of all media, tools and educational facilities. existing in order to achieve the educational goals that have been planned in advance.

\subsection{Forms of Communication in Learning}

In the world of education, forms of communication in learning are better known as interactions in teaching and learning. In this learning interaction, students need the outside world to develop and carry on their life. He always tries to use and change the outside world for his own needs. The point is that in teaching and learning interactions, students will get new relationships. In learning, what is produced by good communication is stimulants, between reactions or between stimulants and reactions.

The important thing that needs attention during the course of the teaching program is the use of various types of learning interactions leading to an optimal direction. Thus the interaction that takes place is not only from teacher to student, but also expected reciprocal interaction between teacher and students, even between fellow students themselves.

The pattern of communication in teaching and learning interactions according to Zahara Idris is divided into two, namely:

1. One-way communication pattern.

2. Two-way communication patterns, which are also divided into:

a. Two-way path for teachers and students.

b. Two-way path for students and children teachers side by side.

c. Two-way path for teacher-students and between students.

Forms of communication (inter-action) in learning are not only one-way communication (one way) from the teacher to students, but lead to optimal communication between teachers and students and between students and students.

In the one way communication pattern, the teacher becomes the center of teaching and learning (teacher centered). Teachers deliver lessons by lecturing, students listen and take notes, so students become passive. In this pattern or form, the teacher plans, controls and fully carries out everything. 
When viewed from the aspect of students, this one-way communication pattern has many disadvantages rather than advantages. The obvious weakness is that the class atmosphere is stiff, the teacher tends to be authoritarian, because the relationship between teachers and students is like employers and subordinates.

In contrast to the two-way form of communication, in this pattern students acquire knowledge in the classroom under the guidance of the teacher or students ask several questions. There is a process of exchanging ideas or giving each other information that challenges students in all learning actions.

In the third form, namely communication between the teacher of students and the child side by side. This path provides more opportunities for students, not only for the teacher to communicate and express his opinion but also to friends who sit on either side of him.

In the last form, namely between teachers and students and between students and students will be able to produce better learning achievement, more efficient, and more effective for students and society, especially for parents. Because this form provides more opportunities for students to ask questions and express their opinions, in addition to the teacher as well as to their classmates.

In the world of education, the principal or the communicant is the student. However, students can not only be seen as objects, but must be included in every educational activity (subject), even the success of student learning is the main spiritual ability to make a threeway relationship.

According to the concept of Islamic education, this student's ability is called a trilogy, namely:

1. Relationship with God, because he is His creature.

2. Relationship with the community, because he is a member of society.

3. Relationship with the surrounding environment, because he as a creature of God who must manage, regulate, take advantage of the natural resources that are above, below, and in the bowels of the earth (Arifin 1991: 45).

Teachers as adults who are responsible for carrying out their duties must always communicate with students in a positive and educational manner. Therefore it is necessary to pay attention to the principles of communication with students, so that communication can be accepted and able to create a harmonious atmosphere for the growth and mental development of students.

In order for teacher-student communication to run well, it is necessary to pay attention to what Alex Sobur said, namely:

"Three recipes are the most basic and key to the success of building intimacy with children. First, we must love our children unconditionally and wholeheartedly. Second, we must understand the traits and development of children, and be willing to listen to them. Third, be creative with them and be able to create a refreshing atmosphere (Sobur. 1986: 9).

In the form of optimal interaction communication between teachers and students and between students and students, it is not only material factors and educational materials that must be considered by teachers and students. Environmental factors also without neglecting the individuals who are not impossible have a greater influence ar.

Another form of educational communication that contributes to the growth and development of student interest and motivation is the good communication relationship between schools, teachers and parents. Because the educational process is categorized as a socialization process, factors that come from outside the child play a role. If communication between parents and teachers and between teachers and students and 
between students and students goes well, students will be more motivated and stimulated to study actively and actively.

\subsection{Factors Affecting Learning Interest}

Talking about the factors that influence student interest in learning in a formal school is certainly inseparable from the existence of teachers who serve in these schools. Because educators are responsible for their students. Ahmad Tafsir said that educators in Islam are people who are responsible for the development of students by striving for the development of all the potential of students, both affective potential, cognitive potential and psychomotor potential (Tafsir. 1992: 74-75).

Educator means adults who are responsible for helping students in physical and spiritual development, in order to reach the level of maturity, able to stand alone to fulfill their maturity level, able to independently fulfill their duties as servants of Allah and khalifah of Allah Almighty and capable as social beings and as creatures independent individual.

An educator is required to be able to play his role and function in carrying out the duties he is assigned as an educator (teacher). This is to avoid a clash of functions and roles, so that educators can place their interests as individuals, members of society, citizens and educators themselves. Between teacher duties and other tasks must be placed in proportion.

According to Roestoyah NK's opinion, the duties and functions of educators in education have three parts, namely:

1. As a teacher in charge of planning teaching programs and implementing programs that have been compiled and ending with the implementation of assessments after the program is carried out.

2. As educators, who lead students at the level of maturity with human personality in line with the purpose of Allah created them.

3. As a leader, who leads self-control, students and the community concerned, which involves directing, supervising, organizing, controlling and participating in the programs carried out (Roestoyah NK. 1992: 86).

In general, teachers are responsible for the smoothness of the teaching and learning process. Therefore, to empower or utilize this education, of course, an educator is required to have a set of teacher principles. The principles of teacher training can be:

1. Passion and willingness to teach, such as paying attention to: the willingness, ability, growth and differences of students.

2. Generating the passion of students.

3. Cultivate the talents and attitudes of good students.

4. Organize a good teaching and learning process.

5. Pay attention to changes in trends that affect the learning process.

6. The existence of a human relationship in the teaching and learning process (Darajat. 1980: 20-23).

Based on the things above, the teacher has a heavy duty in carrying out the tasks that they are assigned, so they must really have a skill in carrying out their mission, because a teacher does not only think about the subject matter to be conveyed to students, but also must think about how the method appropriate to be used in teaching the subject matter.

There are many things that must be mastered by a teacher to empower education, including teaching methods. The teaching method is one of the important educational tools and plays a very big role in the success or failure of education. With the use of the right method, students will find it helpful in understanding the subject matter presented, because 
the method is a tool to make it easier for students to understand the subject matter presented in the field of study. There are many advantages for students if the teacher is able to use the right method in presenting the material presented.

One of the duties and functions of an educator (teacher) is teaching. Of course, a teacher must first prepare things related to the course of teaching. The teaching path is a way of arranging the sequence of learning materials presented to students and how to overcome the difficulties of a subject.

It is a must for a teacher who will teach, planning in advance the teaching path that will be taken so that students can overcome difficulties found in subjects or learning materials.

The path of learning in education can be divided into two things, namely:

1. Way of teaching for a subject.

2. Way of teaching for one hour of lessons / lesson materials.

ad.1. Teaching path for a subject.

The point is a teacher's way of describing or presenting learning materials covered in one subject to students from the lowest class to the highest class in one class level.

This teaching path is divided into four, namely:

1. The path of progressive teaching.

2. Regressive path of teaching.

3. Concentric path of teaching.

4. Mixed teaching paths (Zuhairini. 1989: 106).

ad. 2. The teaching path for one hour of study

The point is how a teacher describes $b$ ahan lessons to students when the teacher teaches. This can be divided into:

1. Deductive teaching path.

2. Inductive teaching path.

So thus the effectiveness of communication between teachers and students will be better if the teacher in carrying out their duties prepares the teaching path optimally. Inequality in preparing the teaching path will make teachers and students unable to unite in understanding the material that has been taught.

Formal education has been outlined and programmed within the scope of the program from various aspects expected of students. Likewise, the complexity of the material and the amount of information that must be conveyed. Programs and information are not only limited to the classroom, as long as the teaching and learning process takes place which covers the entire teaching process in schools. The existence of rules and discipline as well as decisions related to the smoothness of teaching and learning are part of the form of communication that students must understand and implement.

The decisions of such programs often require students to understand complex rules, procedures and orders, which are traditionally given in the form of expressions. Therefore information becomes more and more complex, understanding becomes more difficult and language as the main tool for communication becomes a barrier.

So there are several barriers so that student interest in learning decreases or decreases which also has an impact on learning achievement, namely because of the complexity of the information itself or the media used by the teacher to convey the information is not quite right. Often students are also less able verbally or intellectually or because of scientific limitations on the part of students who are not able to assimilate in processing certain information simultaneously. But whatever the cause, the results remain the same, i.e. what appears to be difficulty in communicating is actually difficulty in learning or teaching and learning interactions. 
Interest is a physical condition, but it is highly dependent on physical conditions and stimuli from outside, namely external factors. In the teaching and learning process, there is student interest, but how much interest is there and how high is the intensity of that interest in learning, it is necessary to get the attention of the teacher. As a general habit that has occurred so far, teachers have tended too far to entrust all problems and the process of teaching and learning interactions to written and spoken language. Even though there are many other ways of communication and strategies that must be considered by teachers, so that maximum student interest in learning is obtained.

\section{Conclusion}

The implementation of communication between teachers and students in a one way system where the teacher provides directions, while students are only waiting for orders, will cause the teaching and learning atmosphere in the classroom to be less dynamic so as not to say it is static.

Good communication patterns, namely between teachers and students and between students and students, will be able to produce better learning achievement, more efficient, and more effective in students. Because this form provides more opportunities for students to ask questions and express their opinions, in addition to the teacher as well as to their classmates.

\section{References}

Abdullah Hanafi. (1984). Memahami Komunikasi Antara Manusia. Surabaya: Usaha Nasional.

Ahmad Tafsir. (1992). Ilmu Pendidikan Dalam Perspektif Islam. Bandung: Remaja Rosdakarya.

Agussani. (n.d.). (2020). Pembinaan Karakter Mahasiswa FISIP UMSU Melalui Pelatihan Soft Skill. Retrieved from file:///C:/Users/youhe/Downloads/kdoc_o_00042_01.pdf

Agussani. (2020). Indonesian Women Entrepreneurs : A Review Literature. 7(4).

Agussani, A., \& Akrim, A. (2020). Enhancing Social Performance Of Ngos Operation In Indonesia Through External Positive Pressure: Mediating Role Of Orientation Dimensions And Sustainable Practices. Journal Of Security And Sustainability, 10(8), 108-122.

Agussani, \& Bahri, S. (2019). A qualitative study on the role of family and social circles among women entrepreneurs in Indonesia. International Journal of Innovation, Creativity and Change, 8(2), 222-239.

Akrim, A., \& Sulasmi, E. (2020). Student perception of cyberbullying in social media. Talent Development and Excellence, 12(1), 322-333.

Akrim, M., \& Harfiani, R. (2019). Daily learning flow of inclusive education for early childhood. Utopia y Praxis Latinoamericana, 24(Extra6), 132-141.

Akrim, Mr. (2018). Media Learning in Digital Era. 231(Amca), 458-460. https://doi.org/10.2991/amca-18.2018.127

Akrim, Nurzannah, \& Ginting, N. (2018). Pengembangan Program Pembelajaran Tematik Terpadu Bagi Guru-Guru SD Muhammadiyah Di Kota Medan. Jurnal Prodikmas:

Hasil Pengabdian Masyarakat, 2(2).

Alex Sobur. (1986). Komunikasi Orang Tua Dan Anak. Bandung: Angkasa.

Astrid S. Susanto. (1988). Komunikasi Dalam Teori Dan Praktek. Bandung: Bina Cipta. 
Amhar, U. (2020). Searching for Critical Thinking through Writing : An Insight into Senior High School Students Written Work in Indonesia. XXIX, 662-669. https://doi.org/10.24205/03276716.2020.769

Aminullah, M. (2019). Human Interaction with Creators and Fellow Creatures (Study of Communication Relations of XYZ in Alamin Theory). Budapest International Research and Critics Institute-Journal (BIRCI-Journal), P.85-98.

Arifin, M., Agussani, \& Rudianto. (2019). Anthropological Approaches in Islamic Studies. 05(2), 263-282. https://doi.org/10.24205/03276716.2020.768

Dadang;, A. H., \& Akrim, A. (2020). Social Welfare: Happy, Healthy, And Wealthy. (1925), 1925-1933.

Engkoswara, et.all. (1992). Ilmu Pendidikan. Bandung: Remaja Rosdakarya.

Gunawan, \& Sulasmi, E. (2020). Math Journaling in Inductive Thinking Learning Models to Enhance Students Self-Regulated Learning ( Theoretical concepts ). XXIX, 623634. https://doi.org/10.24205/03276716.2020.765

Hartanto, D., Hidayat, N., \& Sazali, H. (2019). The Leadership of Head of the Medan City Police Department in Strengthening Community Systems. 292(Agc), 205-209. https://doi.org/10.2991/agc-18.2019.32

Hartanto, D., Radiman, \& Adhani, A. (2020). Journal Of Security And Sustainability Issues Issn 2029-7017 / Issn 2029-7025 ( Online ) 2020 Volume 9 January Journal Of Security And Sustainability Issues Issn 2029-7017 / Issn 2029-7025 ( Online ) 2020 Volume 9 January. Journal Of Security And Sustainability, 9(4), 42-55.

Hasbullah, et al. (2018). Communication Pattern of Wilayatul Hisbah, Lhokseumawe City in Implementing Amar Makruf Nahi Mungkar. Budapest International Research and Critics Institute-Journal (BIRCI-Journal), P. 194-205.

Harsja W. Bachtiar. (1993). Media Pendidikan. Jakarta: PT. Raja Grafindo Persada.

Ibrahim Bafadel. (1992). Supervisi Pengajaran. Jakarta: Bina Aksara.

K. Davies, Ivor. (1991). Pengolahan Belajar. Jakarta: Rajawali Press.

M. Arifin. (1977). Psikolog Dan Beberapa Aspek Kehidupan Manusia. Jakarta: Bulan Bintang.

(1991). Ilmu Pendidikan Islam. Jakarta: Bulan Bintang. (1993). Psikologi Dakwah. Jakarta: Bumi Aksara.

M. Ngalim Purwanto. (1994). Ilmu Pendidikan Teoritis Dan Praktis. Bandung: Remaja Rosdakarya.

Nasrudin, N., Agustina, I., Akrim, A., Ahmar, A. S., \& Rahim, R. (2018). Multimedia educational game approach for psychological conditional. International Journal of Engineering and Technology(UAE), 7(2), 78-81.

Nurzannah; Akrim; Yunus, M. D. (2017). Akidah Akhlak. Medan: UMSU Press.

Onong Uchjana Effendy. (1993). Ilmu Komunikasi Teori Dan Praktek. Bandung: Remaja Rosdakarya.

Prasetia, I., Akrim, \& Sulasmi, E. (2019). Jurnal tarbiyah. 26(2), 294-314.

Priadi, R., \& Rudianto. (2020). Enhancing Sustainable Ecological Footprints through Climate Funds, Green Technology Investments and Research and Development Expenditure: A Panel Data Analysis Of Asean Countries. Journal Of Security And Sustainability, 9(4), 42-55.

Qorib, M., \& Hartanto, D. (2020). Gold Civilization of Mamalic Dynasty and its Contributions for The Islamic World. XXIX, 635-642. https://doi.org/10.24205/03276716.2020.766

Quthb, Muhammad. 1400 H. Manhaj al-Tarbiyyah al-Islamiyyah. Kairo: Dar al-Syuruq. Cetakan IV. Jilid I. 
R.A. Santoso Sastropoetro. (1990). Komunikasi Sosial. Bandung: Remaja Rosdakarya. Roestoyah NK. (1992). Masalah-Masalah Ilmu Keguruan. Jakarta: Bina Aksara.

Samsuddin and Ananda, R. (2019). Communication of School Heads in Improving Education Performancein SMA Plus Private Vocationa School, Al-Azhar Medan. Britain International of Linguistics, Arts and EducationSciences (BIoLAE) Journal, P. 8-15.

Soegarda Poerbawakatja dan A.H. Harahap. 1976. Ensiklopedi Pendidikan. Jakarta: Gunung Agung.

Sulasmi, E. (2019). Analisis faktor-faktor yang mempengaruhi prestasi belajar siswa ditinjau dari aspek manajemen belajar siswa (studi pada siswa smp gajah mada medan). (1).

Sulasmi, E. (2020a). Konsep Pendidikan Humanis Dalam Pengelolaan Pendidikan Di Indonesia. 162. https://doi.org/10.1017/CBO9781107415324.004

Sulasmi, E. (2020b). The Development Strategy of Human Resources Management In Children's Social Welfare Institution ( LKSA) (Case Study in LKSA AL-Mubaraak Orphanage Bengkulu ). 562-569.

Sulasmi, E., \& Akrim, A. (2020). Management construction of inclusion education in primary school. Talent Development and Excellence, 12(1), 334-342.

Syar'i, A., Akrim, A., \& Hamdanah. (2020). The development of higher education in Indonesia. International Journal of Scientific and Technology Research, 9(2), 13811385. https://doi.org/10.24205/03276716.2020.858

T.A. Latief Rousydiy. (1989). Dasar-Dasar Rethorika Komunikasi dan Informasi. Medan: Rinbow.

Zahara Idris. (1981). Dasar-Dasar Kependidikan. Padang: Angkasa.

Zakiah Darajat. (1980). Kepribadian Guru. Jakarta: Bulan Bintang.

Zuhairini. (1989). Metodik Khusus Pendidikan Agama. Surabaya: Usaha Nasional. 